\title{
Technology Assessment of Laser-Assisted Materials Processing in Space
}

\author{
Karthik Nagarathnam ${ }^{1}$ and Karen M. B. Taminger ${ }^{2}$ \\ ${ }^{1}$ Applied Research Center, Old Dominion University, 12050 Jefferson Ave. Suite 717, Newport News, VA 23606, \\ ${ }^{1}$ 757-269-5641, ${ }^{1}$ knagarat@odu.edu \\ ${ }^{2}$ NASA Langley Research Center, MS 188A, Hampton, VA 23681, ${ }^{2} 757-864-3131,{ }^{2}$ k.m.taminger@larc.nasa.gov
}

\begin{abstract}
Lasers are useful for performing operations such as joining, machining, built-up freeform fabrication, shock processing, and surface treatments. These attributes are attractive for the supportability of longer-term missions in space due to the multi-functionality of a single tool and the variety of materials that can be processed. However, current laser technology also has drawbacks for space-based applications, specifically size, power efficiency, lack of robustness, and problems processing highly reflective materials. A review of recent laser developments will be used to show how these issues may be reduced and indicate where further improvement is necessary to realize a laser-based materials processing capability in space. The broad utility of laser beams in synthesizing various classes of engineering materials will be illustrated using state-of-the art processing maps for select lightweight alloys typically found on spacecraft. With the advent of recent breakthroughs in diode-pumped solid-state lasers and fiber optic technologies, the potential to perform multiple processing techniques is increasing significantly. Lasers with suitable wavelengths and beam properties have tremendous potential for supporting future space missions to the moon, Mars and beyond.
\end{abstract}

\section{INTRODUCTION}

The development of a universal tool is essential for supportability of long-term missions in space. In addition to maximized utility, launch costs and power availability in space are primary constraints that will determine whether a tool is sufficiently useful to be included in any mission (with or without human presence). Lasers are useful for performing operations such as surface engineering, built-up freeform fabrication, joining, shock processing, and machining, and are capable of performing these processes on a wide variety of different materials, including metals, ceramics, polymers, and composites. These attributes are attractive for the supportability of longer-term missions in space due to the multifunctionality of a single tool and the variety of materials that can be processed.

However, current laser technology also has drawbacks for space-based applications, which need to be addressed to realize application of lasers for manufacturing in space. Current lasers tend to be large, have low power efficiency, significant maintenance requirements, and difficulty with processing highly reflective materials such as aluminum. Since launch costs per pound are extremely high for current access to space and power supply is quite limited in space missions, these drawbacks are not insignificant.

For moon or Mars-based missions, the time, distance, and cost are prohibitive to effectively provide emergency support from the Earth, necessitating bringing either spare parts or an ability to fabricate or refurbish failed components along on the mission. Unfortunately, it is impossible to know exactly which spare parts will be needed, resulting in a complete inventory of replacement parts, many of which may never be needed and some of which may be omitted. Thus, development of a universal tool for repairing or remanufacturing parts would provide necessary flexibility to build or repair any part needed to ensure the safety and success of long-term, long-distance space missions. Using such a tool, small items such as bolts and fasteners could be fabricated as replacements, and repairs could be made to everything from failed brackets to cracks and impact damage in larger structures. Supportability is crucial for sending astronauts to Mars or establishing a permanent human presence on the moon. Implementation of this technology on the International Space Station would also enhance the astronauts' ability to repair or replace components without reliance on Earth-based support. 


\section{COMPARISON OF LASER TYPES}

The theory that matter can be stimulated to emit photons dates back to Albert Einstein in 1916. The first laser is attributed to Theodore Maiman, who successfully excited a ruby crystal to emit light in 1960. Since the late 1960's, the $\mathrm{CO}_{2}$ laser has been the workhorse in various industrial materials processing applications. Over the past decade, the neodymium ion-doped yttrium aluminum garnet (Nd:YAG) solid-state lasers have become increasingly popular for manufacturing applications, due to better absorptivity and the ability to use fiber optics for beam transport.

In pulsed solid-state lasers such as Nd:YAG, Q-switching is commonly used to obtain pulses of various lengths and frequencies (up to $50 \mathrm{MHz}$ ). Using a frequency doubling technique, the $1.06 \mu \mathrm{m}$ wavelength can be sent through aligned crystals such as lithium niobate to obtain visible green wavelength $(532 \mathrm{~nm})$. The rod geometry of the YAG has been modified into a slab- or face-pumped geometry to generate very high peak powers with reduced thermal lensing and beam distortion. The diode-pumped solid-state laser has much longer life (several thousands of hours) than that of the krypton arc lamp-pumped lasers, which lasts only few hundred hours. Diode pumping also results in higher brightness and monochromacity, more efficient coupling with the lasing medium (such as Nd ions), and more compact size, which are effective at reducing thermal losses in solid-state lasers. Some solid-state lasers like the Tisapphire laser are capable of ultra-short pulse lengths (ps or fs); although attractive for diagnostics, micro-machining and ablation in a small scale, this laser is not suitable for many other processing and manufacturing techniques.

A number of alternative lasers with varying wavelengths and power levels are also available. Both fast axial flow and transverse flow continuous wave gas lasers are available with high power levels up to $100 \mathrm{~kW}$. Among the pulsed lasers, the transverse excitation atmospheric (TEA) laser is popular to attain high peak powers of MW and higher pulse energy $(10 \mathrm{~J})$ and pulse length $(2-3 \mathrm{~ms})$. Excimer UV lasers $(\mathrm{KrF}, \mathrm{XeCl})$ are pulsed chemical lasers with UV wavelengths, very short pulse lengths, and high peak powers, but fairly low average powers of only a few watts. Copper vapor lasers (532 nm wavelength) exhibit intermediate average powers and high peak powers, and chemical oxygen-iodine lasers (COIL, $1.315 \mu \mathrm{m}$ wavelength) have scalable high power levels up to $40 \mathrm{~kW}$. However, chemical and gas lasers are typically bulky in size and require handling chemicals, frequent maintenance, and elaborate cooling systems, which make them less attractive for processing in space.

Diode lasers, typically GaAs, GaAlAs (750-870 nm wavelength), and InGaAs (900-1000 nm wavelength), are the most compact of the different types of lasers. Although diode lasers are typically low power, they can be used for efficient pumping of solid-state lasers. The desirable wavelengths for optimum energy absorption for reflective alloys include visible end $(511 \mathrm{~nm})$ to near-infrared $(1.06 \mu \mathrm{m})$ wavelengths as found in solid-state lasers. The wall plug efficiency of early generation Nd:YAG lasers was only $2 \%$, but the advent of diode lasers as pumping sources has increased efficiencies for $\mathrm{Nd}$ :YAG lasers up to $30-40 \%$. As a reference, $\mathrm{CO}_{2}$ lasers have a typical efficiency of approximately $12 \%$. Although the demonstrated increases in efficiency are encouraging, power efficiency needs to be further improved to make laser manufacturing in space feasible, due to strict power limitations in space.

\section{LASER-ASSISTED MATERIALS PROCESSING REQUIREMENTS}

Figure 1 shows general regimes of various laser materials processing parameters for both pulsed and continuous wave lasers. Short pulses (ns to fs) with high peak power densities are desirable for laser shock processing, drilling, machining, and ablation applications. In general, longer pulses ( $\mu \mathrm{s}$ to $\mathrm{ms}$ ) or continuous wave lasers are preferred for melting, freeform fabrication, and welding operations, as well as hybrid combinations of processing such as meltquenching and heat treatment. Laser chemical vapor deposition and laser surface transformation hardening require lower power densities and interaction times as compared to processes involving melting and vaporization.

Representative laser processing research efforts and the resulting properties (e.g., grain refinement, homogeneity, enhanced corrosion resistance, increased microhardness and fatigue strength) of aluminum and titanium based alloys are summarized in Table 1 (included as an appendix due to the length of this table). These results demonstrate that both $\mathrm{CO}_{2}$ and $\mathrm{Nd}$ :YAG lasers are capable of performing numerous operations on high reflectance, non-ferrous alloys. 


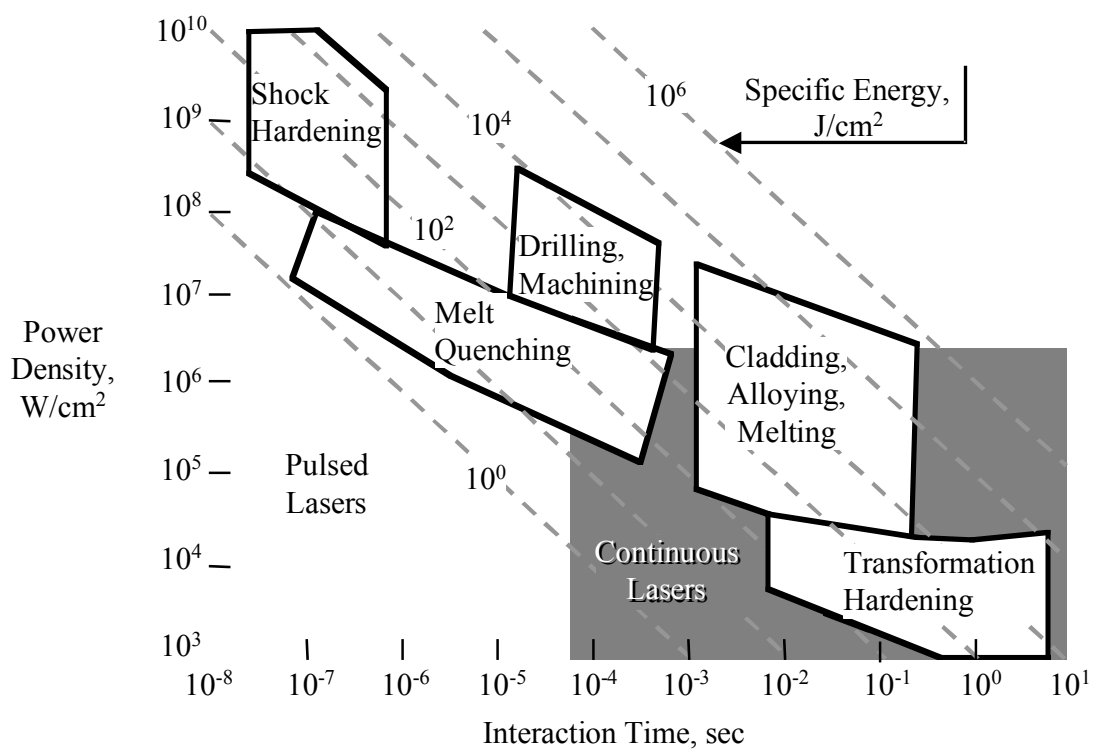

FIGURE 1. Laser power density, specific energy and interaction times for various laser processing regimes.

\section{Laser Surface Engineering}

Materials have been traditionally processed in such a way that their properties were optimized with respect to bulk as well as surface constraint requirements. This is inherently a difficult task as the properties required at the surface (fatigue, wear and corrosion) are often very different from those in the bulk (strength and toughness). The use of lasers in processing selective areas without affecting the bulk material is a development with potential for optimizing engineered surfaces without compromising the bulk properties.

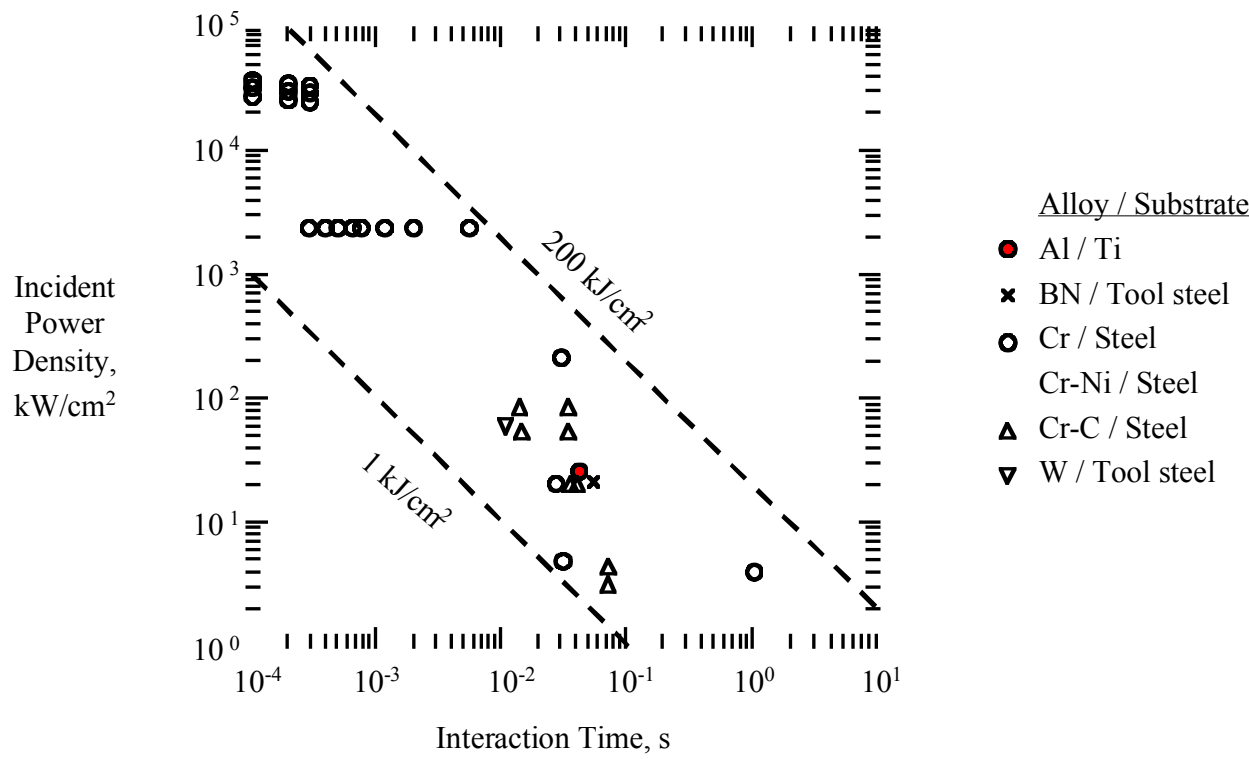

FIGURE 2. Laser processing map for laser surface alloying.

Laser surface modification has been proven to improve the wear resistance and/or high temperature corrosion resistance in several ferrous and non-ferrous alloy systems. Figures 2 and 3 show laser processing maps for general processing regimes in several different alloy systems for laser surface alloying and laser surface cladding, respectively. Alternatively, coatings treated by other processing techniques such as plasma spraying or 
electroplating may be modified with laser beams. Lasers in the infrared regions (10.6-1.06 $\mu \mathrm{m}$ wavelength) have also been used to process alloys such as aluminum, titanium and copper alloys. Unlike conventional castings or heat treatment, it is possible to have much higher cooling rates with laser processing. These rapid solidification rates result in superior fine-grained microstructures with metastable crystalline and/or amorphous phases, uniform alloy composition, and extended solubility of alloying elements.

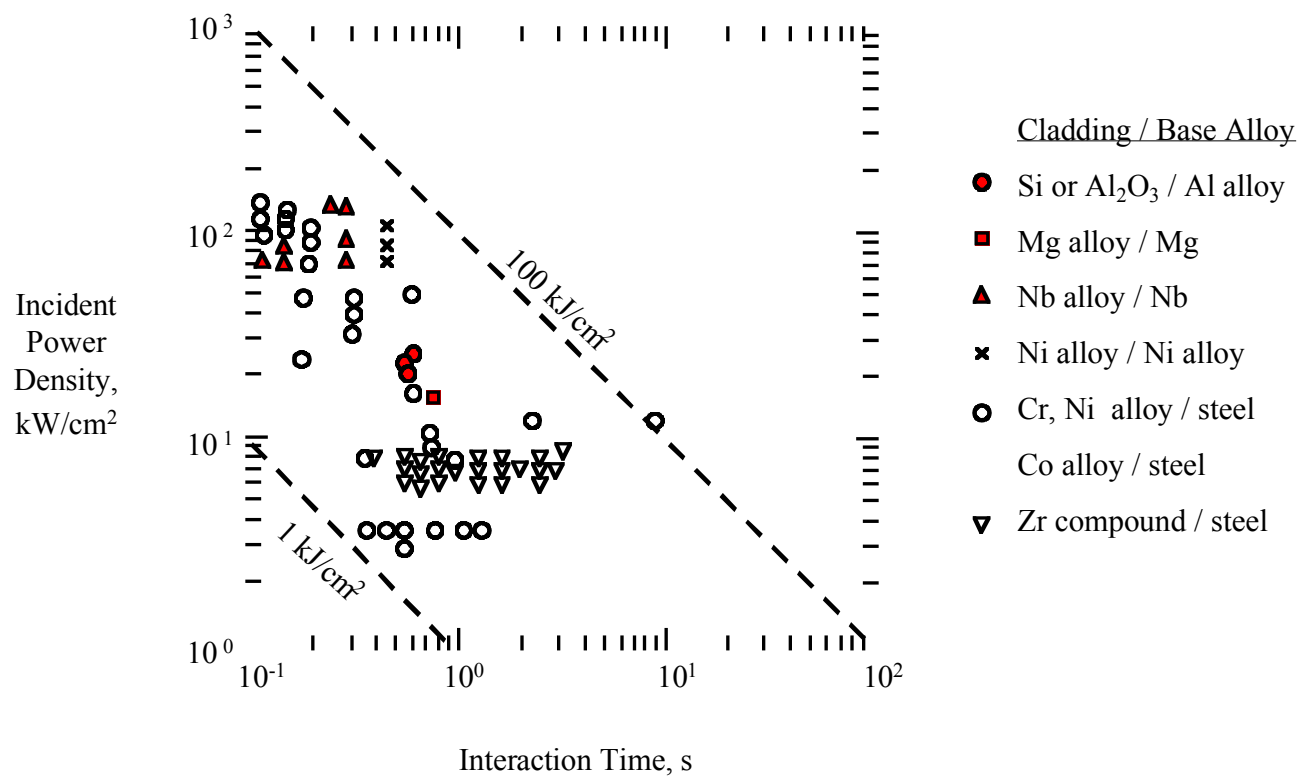

FIGURE 3. Laser processing map for laser surface cladding.

\section{Built-up Freeform Fabrication}

Shallow depth of penetration of laser energy into the bulk material can be a benefit, as seen in the surface engineering field. However, to affect bulk material properties with laser processing, techniques originally developed for laser surface cladding or alloying need to be applied in a built-up process. One built-up freeform fabrication process employs a laser beam to create a small melt pool on the surface of a metallic substrate. Metallic powder is fed into the molten pool in a layer-by-layer process, resulting in a fully dense, structural part built directly from computer-aided design models without molds, tooling, or machining. The resulting microstructure throughout the bulk is typically much finer than that in conventionally produced materials due to rapid solidification kinetics associated with the small melt pool. Due to the ability to blend alloy powders, it is possible to produce unique materials that are compositionally tailored and functionally graded in a unitized structure. The process is flexible enough to be able to build near-net shaped parts in complex geometries, which can be net-shape if surface roughness is not an issue. Although not documented in other materials to date, two distinctly different microstructures were obtained in Ti-6Al-4V with different laser settings (Schlienger, 1998). This provides evidence that both compositions and microstructures may be controlled and tailored during the fabrication process.

Laser freeform fabrication, using fiber optic delivery, has tremendous potential for revolutionizing the use of lasers in space manufacturing applications because it provides a means by which to build up structures. This process can be modified to use wire feed to eliminate the handling of powder feedstock in a zero or low-gravity atmosphere. The process typically is performed in a glove box under inert gas shielding, but the enclosure and gas shielding requirements can be eliminated in the relative vacuum in the space environment. The built-up freeform fabrication process is computer controlled, and could be fully automated to operate with minimal to no human intervention. All of these attributes are advantageous for attended or unattended operation in space manufacturing applications. 


\section{Laser Welding, Machining, and Other Manufacturing Applications}

Lasers are useful in other areas of manufacturing such as welding, micro-machining, solid-state transformation hardening, melt quenching, melt-particle injection, and laser shock processing of ferrous, non-ferrous, ceramic, cermet and composite engineering materials. Laser processing maps for laser welding and melt quenching are shown in Figs. 4 and 5 respectively. Autogenous laser welding has been successfully performed on numerous ferrous and non-ferrous alloys. Laser welding produces very small heat affected zones and typically requires no post-weld heat treatment. Precision laser micro-machining can be accomplished on a variety of different materials, including metal matrix composites, which can cause rapid tool wear in traditional machining because of the hard reinforcement phase within the more ductile metal matrix. Nd:YAG lasers have been used to micro-machine SiC reinforced aluminum composite without much heat affected zone or recast layer (Nagarathnam, et al., 1997). Since lasers are non-contacting, they do not suffer tool wear. Lasers are also capable of machining extremely delicate details using a small beam diameter, and with fiber optic technology can perform keyhole drilling. Laser meltparticle injection is used to create in-situ composite coatings by melting only the substrate and injecting hard particles like oxides or carbides during the co-deposition. Laser shock processing is a new technique that introduces compressive residual stresses deep into the bulk material to improve the resistance to surface-related failures such as fatigue, fretting fatigue, and stress corrosion cracking.

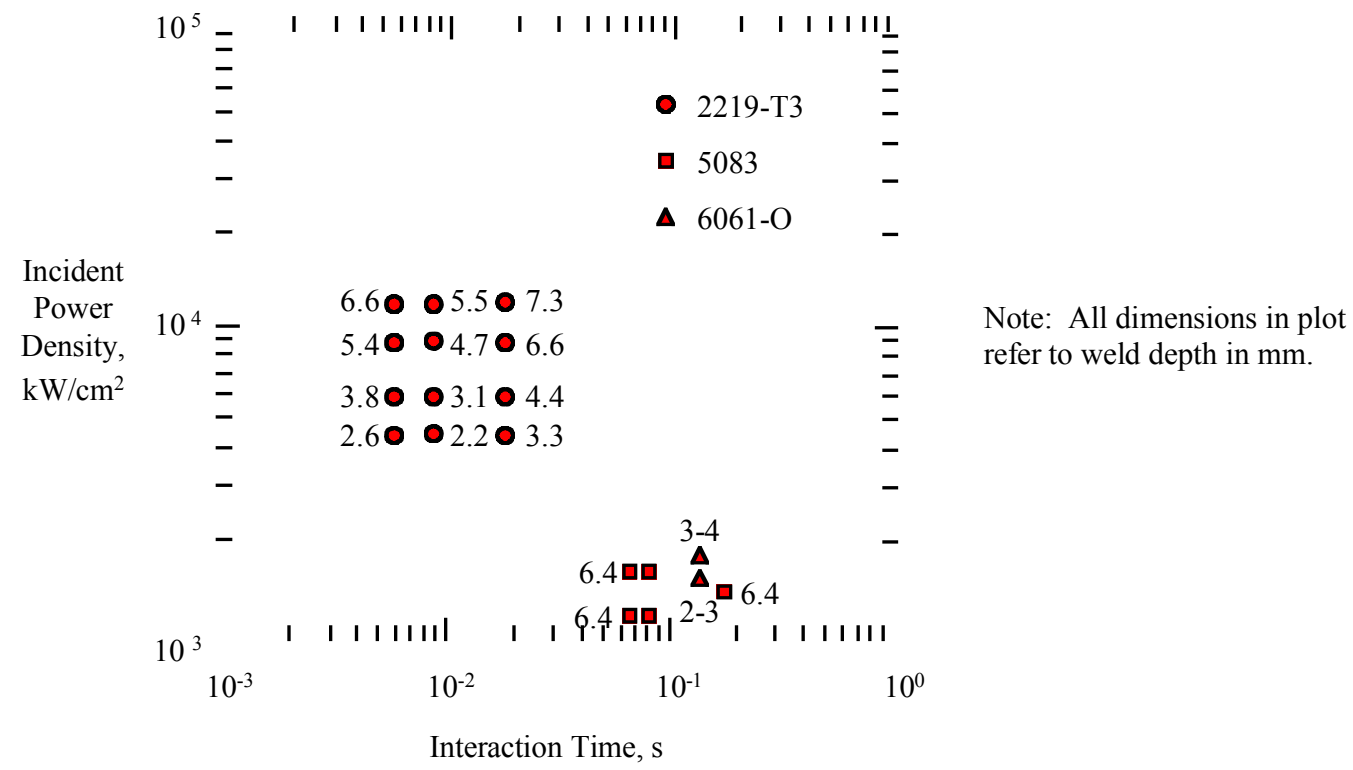

FIGURE 4. Laser processing map for laser welding of aluminum alloys.

The required laser power density, specific energy and interaction time requirements typical for $\mathrm{CO}_{2}$ laser processing are given in Table 2. Compared to the solid-state transformation hardening, it is obvious to see the high power density requirements for surface melting processes. When using solid-state lasers with shorter wavelengths (1.06 $\mu \mathrm{m}$ or lower), the reflectivity problems with aluminum alloys are reduced significantly. The required energy densities and times are correspondingly reduced due to the higher absorptivities, thereby also reducing the input energy requirements.

TABLE 2. $\mathrm{CO}_{2}$ Laser Materials Processing Parameters for Various Surface Engineering Applications.

\begin{tabular}{|c|c|c|c|}
\hline Surface Engineering Process & $\begin{array}{c}\text { Laser Power Density } \\
\text { (Power/Beam Area), } \\
\text { kW/cm }\end{array}$ & $\begin{array}{c}\text { Specific Energy } \\
\text { (Power/Beam Size Speed), } \\
\mathrm{J} / \mathrm{cm}^{2}\end{array}$ & $\begin{array}{c}\text { Laser Beam Interaction } \\
\text { Time (Beam Size/Speed), } \\
\text { s }\end{array}$ \\
\hline Laser Surface Transform. Hardening & $0.8-40$ & $0.3-60$ & $0.04-9$ \\
\hline Laser Surface Melt-Quenching & $2.5-7000$ & $0.3-200$ & $0.001-9$ \\
\hline Laser Surface Alloying & $3-40000$ & $1-200$ & $0.001-10$ \\
\hline Laser Surface Cladding & $3-150$ & $1-100$ & $0.1-10$ \\
\hline Laser Melt-Particle Injection & $30-310$ & $5-30$ & $0.04-0.55$ \\
\hline
\end{tabular}




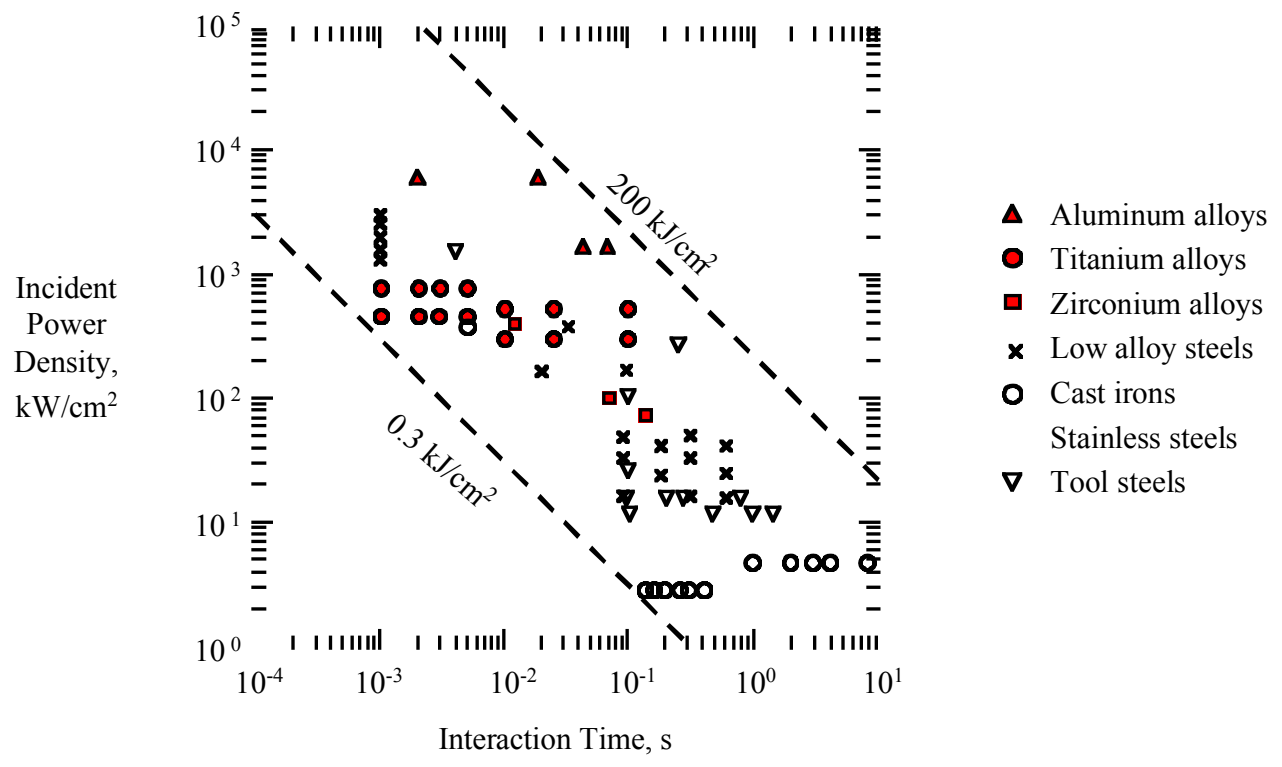

FIGURE 5. Laser processing map for laser surface melt quenching.

Based on several experimental findings, typical laser processing maps were developed for surface engineering applications, and are shown for laser surface alloying (Fig. 2), laser surface cladding (Fig. 3), laser beam welding (Fig. 4), and laser surface melt quenching (Fig. 5) (Nagarathnam and Mazumder, 1996). These laser processing maps show the required laser parameters for a variety of ferrous and non-ferrous based alloys for each of the different techniques. Processing maps are useful for defining key laser variables for processing new alloys, and for comparing the range of laser settings used for performing different laser techniques. Most of these techniques can be carried out with the same laser setup by proper choice of fixturing. Addition of feedstock supply and computercontrolled positioning capability can expand a standard laser arrangement to be capable of built-up freeform fabrication. Thus, if a single type of laser can attain the range of settings in these different processing maps, that laser would be extremely versatile in performing many different processing operations on a variety of materials.

\section{SUMMARY}

Diode-pumped solid-state lasers are inherently well suited to be used as a multifunctional tool because they have characteristic wavelengths and power outputs suitable for numerous materials including reflective alloys and for most laser processing techniques. These lasers are also capable of fiber optic delivery, which greatly increases laser manufacturing flexibility by expanding the ability to treat complex geometries and inaccessible areas with less difficulty. In addition, diode-pumped solid-state lasers are well suited for adapting to space applications due to their compact size, robustness, and minimal cooling requirements. Establishing an in-space laser manufacturing capability will require significant improvements over state-of-the-art laser technology in power efficiency, maximized life with minimal maintenance, and ability to operate using DC input power. Ongoing development of these types of lasers addressing manufacturing issues on earth will contribute to increasing versatility and feasibility of lasers for supportability of short- and long-term missions on-orbit, the moon, Mars, and beyond.

\section{REFERENCES}

Abboud, J. H., and West, D. R. F., "Processing Aspects of Laser Surface Alloying of Titanium with Aluminum," Mat. Sci. \& Tech., 7 No. 4, 353-356 (1991).

Almeida, et al., "Laser Alloying of Aluminum Alloys with Chromium," Surf. \& Coatings Tech., 70, 221-229 (1995). Berthe, et al., "Laser-Shock Surface Processing of Materials," ASM Surf. Eng. Series, 1, 465-503 (1998).

Bharti, A., Sivakumar R., and Goel, D. B., J. of Laser Appl., March, p. 43 (1989).

Coyle, et al., "Laser Welding in the Assembly of a High Reliability Al Alloy Amplifier Housing," in Proc. of the 
Intl. Conf. on the Appl. of Lasers \& Electro-Optics (ICALEO), San Diego, CA, Nov. 1997, pp. 75-82.

$\mathrm{Fu}$, Y., and Batchelor, A. W., "Laser Alloying of Aluminum Alloy AA6061 with Ni and Cr. Part II. The Effect of

Laser Alloying on the Fretting Wear Resistance," Surf. \& Coatings Tech., 102, 119-126 (1998).

Das, D. K., et al., "Evolution of Microstructure in Laser Surface Alloying of Aluminum with Nickel," Mat. Sci. \& Eng., A174, 75-84 (1994).

Katsuna, M., et al., Welding in the World, 31 No. 2, 126-135 (1993).

Kelly, J., Nagarathnam, K., and Mazumder, J., "Processing and Characterization of Laser Cladded Cu-Sn-Zn Coatings on Cast Aluminum Alloys," in Proc. of the Intl. Conf. on the Appl. of Lasers \& Electro-Optics (ICALEO), San Diego, CA, Nov. 1995, 80, pp. 477-486.

Kelly, J., Nagarathnam, K., and Mazumder, J., "Laser Cladding of Cast Aluminum-Silicon Alloys for Improved Dry Sliding Wear Resistance," J. of Laser Appl., 10 No. 2, 45-54 (1998).

Nagarathnam, K., "Processing and Characterization of Laser-Synthesized Overcoats for Surface Engineering," Ph.D.

Thesis, Dept. of Mechanical and Industrial Eng., Univ. of Illinois at Urbana-Champaign, Oct. 1994.

Nagarathnam, K., and Komvopoulos, K., "Microstructural Analysis and Oxidation Behavior of Laser Processed FeCr-Al-Y Alloy Coatings," Met. Trans. A, 27A, 381-390 (1996).

Nagarathnam, K., and Mazumder, J., "Development of Processing Maps and Comprehensive Database for the Laser Beam Welding of Various Engineering Materials," DARPA Project Reports, Oct. 1994-1996.

Nagarathnam, K., Chen, X., and Mazumder, J., "Scientific Implications in High Peak Power Nd:YAG Laser

Material Removal of Al-30\% SiC Composite," International Mechanical Eng. Conf. \& Exposition (IMEC \& E), Recent Adv. in Solids/Structures \& Appl. of Met. Mat., 369, 389-398 (1997).

Ramaswamy, et al., " $\mathrm{CO}_{2}$ and Nd:YAG Laser Beam Welding of 6114-T4 Aluminum Alloy for Automotive Applications," J. of Laser Appl., 12 No. 3, 101-115 (2000).

Schlienger, M. E., et al., "Titanium Processing with LENS," TMS Annual Mtg., San Antonio, TX, Feb. 1998.

Whitaker, I., et al., "Microstructural Characterization of $\mathrm{CO}_{2}$ Laser Welds in the Al-Li Based Alloy 8090," J. of Mat. Sci., 28 No. 20, 5469-5477 (1993).

\section{APPENDIX}

TABLE 1. Typical Processing Parameters and Results of Laser-Processed Aluminum and Titanium-Based Materials.

\begin{tabular}{|c|c|c|c|c|c|}
\hline Material & $\begin{array}{l}\text { Type of } \\
\text { Laser } \\
\text { Process } \\
\end{array}$ & $\begin{array}{l}\text { Laser } \\
\text { Type Used }\end{array}$ & $\begin{array}{l}\text { Typical Process } \\
\text { Parameters }\end{array}$ & Comments & Reference \\
\hline $\begin{array}{l}7175 \mathrm{Al} \\
\text { substrate/ } \\
\text { Cr alloying }\end{array}$ & $\begin{array}{l}\text { Laser } \\
\text { surface } \\
\text { alloying }\end{array}$ & $\begin{array}{l}\text { Continuous } \\
\text { wave } \mathrm{CO}_{2}\end{array}$ & $\begin{array}{l}\text { Power Density: } 120-260 \\
\mathrm{~kW} / \mathrm{cm}^{2} \\
\text { Interaction Time: } .04-.3 \mathrm{~s} \\
\text { Scanning Rate: } 5,10 \mathrm{~mm} / \mathrm{s} \\
\text { Remelting Rate: } 10,20 \mathrm{~mm} / \mathrm{s}\end{array}$ & $\begin{array}{l}\mathrm{VHN}=155(\mathrm{Cr} \text {-alloyed } \mathrm{Al}) \\
\mathrm{VHN}=300(\mathrm{Cr} \text {-alloyed } \\
7175) \text {; reduced porosity } \\
\text { after remelting; improved } \\
\text { pitting corrosion resistance } \\
\text { with } \mathrm{Cr} ; \mathrm{Al}_{7} \mathrm{Cr}, \mathrm{Al}_{11} \mathrm{Cr}_{2} \& \\
\alpha-\mathrm{Al} \text { phases }\end{array}$ & $\begin{array}{l}\text { Almeida, et } \\
\text { al., } 1995\end{array}$ \\
\hline $\begin{array}{l}\text { Ti substrate/ } \\
\text { Al alloying }\end{array}$ & $\begin{array}{l}\text { Laser } \\
\text { surface } \\
\text { alloying }\end{array}$ & $\begin{array}{l}\text { Continuous } \\
\text { wave } \mathrm{CO}_{2}\end{array}$ & $\begin{array}{l}\text { Power: } 1.8 \mathrm{~kW} \\
\text { Beam Diameter: } 3 \mathrm{~mm} \\
\text { Process Speed: } 3-20 \mathrm{~mm} / \mathrm{s} \\
\text { Powder Feed: } 0.03-0.11 \mathrm{~g} / \mathrm{s}\end{array}$ & $\begin{array}{l}\text { Alloy is homogeneous \& } \\
\text { reproducible; alloy build-up } \\
\text { thickness: } 0.2-0.9 \mathrm{~mm} ; 17- \\
80 \% \mathrm{Al} \text { conc. with increase } \\
\text { in powder feed rates }\end{array}$ & $\begin{array}{l}\text { Abboud, et } \\
\text { al., } 1991\end{array}$ \\
\hline $\begin{array}{l}\text { Ti-6Al-4V } \\
\text { substrate/ } \\
\text { C alloying }\end{array}$ & $\begin{array}{l}\text { Laser } \\
\text { surface } \\
\text { alloying }\end{array}$ & $\begin{array}{l}\text { Continuous } \\
\text { wave } \mathrm{CO}_{2}\end{array}$ & $\begin{array}{l}\text { Laser Power: } 3 \mathrm{~kW} \\
\text { Process Speed: } 17-42 \mathrm{~mm} / \mathrm{s}\end{array}$ & $\begin{array}{l}\text { Dendritic \& cellular } \\
\text { structures; roughness decr. } \\
50 \rightarrow 10 \mu \mathrm{m} \& \text { chemical } \\
\text { homogeneity improves as \# } \\
\text { of scans incr. from } 0 \rightarrow 4\end{array}$ & $\begin{array}{l}\text { Bharti, et al., } \\
1989\end{array}$ \\
\hline $\begin{array}{l}6061 \mathrm{Al} \\
\text { substrate/ } \\
\mathrm{Ni}, \mathrm{Cr} \text { alloying } \\
\end{array}$ & $\begin{array}{l}\text { Laser } \\
\text { surface } \\
\text { alloying } \\
\end{array}$ & $\begin{array}{l}\text { Continuous } \\
\text { wave } \\
\text { Nd:YAG }\end{array}$ & $\begin{array}{l}\text { Power Density: } 30 \mathrm{~J} / \mathrm{mm}^{2} \\
\text { Beam Diameter: } 2 \mathrm{~mm} \\
\text { Scanning Rate: } 6 \mathrm{~mm} / \mathrm{s}\end{array}$ & $\begin{array}{l}\text { Fretting wear \& coefficient } \\
\text { of friction reduced } \\
\text { significantly }\end{array}$ & $\begin{array}{l}\text { Fu, et al., } \\
1998\end{array}$ \\
\hline $\begin{array}{l}\text { Pure Al } \\
\text { substrate/ } \\
\text { Ni alloying }\end{array}$ & $\begin{array}{l}\text { Laser } \\
\text { surface } \\
\text { alloying }\end{array}$ & $\begin{array}{l}\text { Pulsed } \\
\text { Nd:YAG }\end{array}$ & $\begin{array}{l}\text { Power: } 120 \mathrm{~W} \\
\text { Pulse Width: } 4 \mathrm{~ms} \\
\text { Repetition Rate: } 10 \mathrm{~Hz} \\
\text { Speed: } 2.1 \mathrm{~mm} / \mathrm{s} \\
\% \text { Overlap of Tracks: } 65 \%\end{array}$ & $\begin{array}{l}\alpha-\mathrm{Al} \text {, lamellar eutectic of } \alpha \text { - } \\
\mathrm{Al} \& \mathrm{Al}_{3} \mathrm{Ni} \& \text { primary } \\
\mathrm{Al}_{3} \mathrm{Ni} \text { dendrites depending } \\
\text { on the Ni contents }(6-15 \% \text { in } \\
\text { alloyed zone) }\end{array}$ & $\begin{array}{l}\text { Das, et al., } \\
1994\end{array}$ \\
\hline
\end{tabular}




\begin{tabular}{|c|c|c|c|c|c|}
\hline $\begin{array}{l}\text { Cu substrate/ } \\
\text { Al alloying }\end{array}$ & $\begin{array}{l}\text { Laser } \\
\text { surface } \\
\text { alloying }\end{array}$ & $\begin{array}{l}\text { Pulsed } \\
\text { Nd:YAG }\end{array}$ & $\begin{array}{l}\text { Power: } 160 \mathrm{~W} \\
\text { Beam Size: } 0.45 \mathrm{~mm} \\
\text { Pulse Duration: } 2 \mathrm{~ms} \\
\text { Frequency: } 10 \mathrm{~Hz} \\
\text { Process Speed: } 1 \mathrm{~mm} / \mathrm{s}\end{array}$ & $\begin{array}{l}\text { Non-ferrous martensitic } \\
\text { microstructures; improved } \\
\text { mechanical strength \& wear } \\
\text { resist. }\end{array}$ & \\
\hline $\begin{array}{l}\text { 316L stainless } \\
\text { steel substrate/ } \\
\text { MCrAlY alloy } \\
\text { coatings }\end{array}$ & $\begin{array}{l}\text { Laser } \\
\text { surface } \\
\text { cladding }\end{array}$ & $\begin{array}{l}\text { Continuous } \\
\text { wave } \\
\text { Nd:YAG }\end{array}$ & $\begin{array}{l}\text { Laser Power: } 0.6-2.4 \mathrm{~kW} \\
\text { Process Speed: } 0.53-4.23 \\
\mathrm{~mm} / \mathrm{s} \\
\text { Powder Feed Rate: } 0.083 \mathrm{~g} / \mathrm{s} \\
\text { Beam Delivery: fiber optic }\end{array}$ & $\begin{array}{l}\text { Homogeneous single phase } \\
\alpha \text { Fe-Cr-Al microstructure } \\
\text { with sufficient } \mathrm{Y} ; 15-150 \\
\mu \mathrm{m} \text { grain sizes; improved } \\
\text { high temp. oxidation resist. } \\
\text { at } 1200^{\circ} \mathrm{C}\end{array}$ & $\begin{array}{l}\text { Nagarathnam, } \\
\text { et al., } 1996\end{array}$ \\
\hline $\begin{array}{l}\text { Cast } 390 \& 333 \\
\text { Al-Si alloy } \\
\text { substrate/ } \\
\text { Sn \& Mn- } \\
\text { bronze alloy } \\
\text { coatings }\end{array}$ & $\begin{array}{l}\text { Laser } \\
\text { surface } \\
\text { cladding }\end{array}$ & $\begin{array}{l}\text { Continuous } \\
\text { wave } \mathrm{CO}_{2}\end{array}$ & $\begin{array}{l}\text { Power: } 2.3-2.5 \mathrm{~W} \\
\text { Process Speed: } 14-16 \mathrm{~mm} / \mathrm{s} \\
\text { Powder Feed Rate: } 0.7 \mathrm{~g} / \mathrm{s} \\
\text { Specific Energy: } 34-48 \\
\mathrm{~J} / \mathrm{mm}^{2}\end{array}$ & $\begin{array}{l}\text { Fine grained microstructure } \\
\text { of primary } \alpha \text {-phase \& } \\
\text { eutectic interdendritic } \\
\text { phases; increased hardness, } \\
\text { toughness \& improved } \\
\text { sliding wear resistance }\end{array}$ & $\begin{array}{l}\text { Kelly, et al., } \\
1995,1998\end{array}$ \\
\hline $\begin{array}{l}2219,5083 \\
6063 \mathrm{Al} \\
\end{array}$ & $\begin{array}{l}\text { Laser beam } \\
\text { welding }\end{array}$ & $\begin{array}{l}\text { Continuous } \\
\text { wave } \mathrm{CO}_{2}\end{array}$ & Power: $3,4,6 \& 8 \mathrm{~kW}$ & $\begin{array}{l}\text { Penetration depths: } 3.25 \text {, } \\
4.30,6.5, \& 7.10 \mathrm{~mm}\end{array}$ & $\begin{array}{l}\text { Katsuna, et } \\
\text { al., } 1993\end{array}$ \\
\hline $6061,4047 \mathrm{Al}$ & $\begin{array}{l}\text { Laser beam } \\
\text { welding }\end{array}$ & $\begin{array}{l}\text { Pulsed } \\
\text { Nd:YAG }\end{array}$ & $\begin{array}{l}\text { Power: } 20 \mathrm{~W} \\
\text { Pulse Duration: } 7 \mathrm{~ms} \\
\text { Frequency: } 1 \mathrm{~Hz} \\
\text { Shield Gas: } \mathrm{Ar} \\
\end{array}$ & Successful welding & $\begin{array}{l}\text { Coyle, et al., } \\
1987\end{array}$ \\
\hline 6111-T4 Al & $\begin{array}{l}\text { Laser beam } \\
\text { welding }\end{array}$ & $\begin{array}{l}\text { Continuous } \\
\text { wave } \\
\text { Nd:YAG }\end{array}$ & $\begin{array}{l}\text { Power: } 2 \mathrm{~kW} \\
\text { Weld Speed: } 42-63 \mathrm{~mm} / \mathrm{s} \\
\text { Beam Diameter: } 0.5 \mathrm{~mm} \\
\text { Sheet metal thickness: } 1 \mathrm{~mm} \\
\text { Beam Delivery: } 1 \mathrm{~mm} \text { fiber } \\
\text { optic }\end{array}$ & $\begin{array}{l}\text { Reduced weld hardness due } \\
\text { to solutionizing effect; } \\
\text { cellular dendrites in fusion } \\
\text { zone with equiaxed grains at } \\
\text { weld center; successful } \\
\text { autogenous butt welding; no } \\
\text { post weld heat treatment }\end{array}$ & $\begin{array}{l}\text { Ramaswamy, } \\
\text { et al., } 2000\end{array}$ \\
\hline $8090 \mathrm{Al}$ & $\begin{array}{l}\text { Laser beam } \\
\text { welding }\end{array}$ & $\begin{array}{l}\text { Continuous } \\
\text { wave } \mathrm{CO}_{2}\end{array}$ & $\begin{array}{l}\text { Power: } 1.5-3.8 \mathrm{~kW} \\
\text { Scanning Rate: } 20-120 \mathrm{~mm} / \mathrm{s} \\
\text { Beam Diameter: } 0.25 \mathrm{~mm} \\
\text { Coaxial He Flow: } 401 / \mathrm{min} \\
\text { Sheet Thickness: } 2-3.2 \mathrm{~mm} \\
(60 \mathrm{~mm} / \mathrm{s}-\text { full weld } \\
\text { penetration }) 4 \mathrm{~mm}(60 \mathrm{~mm} / \mathrm{s}- \\
\text { partial weld penetration })\end{array}$ & $\begin{array}{l}2-5 \mu \mathrm{m} \text { secondary dendrite } \\
\text { arm spacing; columnar \& } \\
\text { equiaxed grains; fine scale } \\
\delta^{`}\left(\mathrm{Al}_{3} \mathrm{Li}\right) \text { ppts. within } \alpha- \\
\text { phase; increased hardness; } \\
\text { porosity along weld } \\
\text { centerline }\end{array}$ & $\begin{array}{l}\text { Whitaker, et } \\
\text { al., } 1993\end{array}$ \\
\hline $\begin{array}{l}\mathrm{A} 1-30 \% \mathrm{SiC} \\
\text { particulate } \\
\text { composite }\end{array}$ & $\begin{array}{l}\text { Laser } \\
\text { micro- } \\
\text { machining }\end{array}$ & $\begin{array}{l}\text { Diode- } \\
\text { pumped } \\
\text { Nd:YAG }\end{array}$ & $\begin{array}{l}\text { Wavelengths: } \\
532 \mathrm{~nm} \text { (green) at } 35 \mathrm{~W} \\
1064 \mathrm{~nm} \text { (IR) at } 85-90 \mathrm{~W} \\
\text { Power: } 35-90 \mathrm{~W} \\
\text { Modes: Q-switch+ Mode } \\
\text { Lock: } 150 \mathrm{ps} \text { pulses }(13 \mathrm{~ns} \\
\text { apart) at } 76 \mathrm{MHz} \\
\text { Q-Switch }(5 \mathrm{kHz} \& 300 \mathrm{~ns}) \\
\text { Process time: Up to } 180 \mathrm{~s} \\
\text { Assist Gas: } \mathrm{O}_{2}\end{array}$ & $\begin{array}{l}\text { Straight } \& \text { angular holes; no } \\
\text { recast layer \& heat affected } \\
\text { zone under optimum } \\
\text { conditions; hole depths: } 85- \\
420 \mu \mathrm{m} \text {; hole width: } 30-425 \\
\mu \mathrm{m} \text {; higher material removal } \\
\text { rate at } 532 \mathrm{~nm} \text { wavelength }\end{array}$ & $\begin{array}{l}\text { Nagarathnam, } \\
\text { et al., } 1997\end{array}$ \\
\hline $\begin{array}{l}7075,2024, \\
\text { A356 Al }\end{array}$ & $\begin{array}{l}\text { Laser } \\
\text { shock } \\
\text { processing }\end{array}$ & $\begin{array}{l}\text { Pulsed } \\
\text { Nd:YAG }\end{array}$ & $\begin{array}{l}\text { Pulsed Duration: } 5-40 \mathrm{~ns} \\
\text { Power Density: } 1-10 \\
\text { GW/cm }{ }^{2} \\
\text { Frequency: } 1-5 \mathrm{~Hz} \\
\text { Water Confined Medium }\end{array}$ & $\begin{array}{l}\text { Incr. residual compressive } \\
\text { stress } 50-60 \% \text { of yield; incr. } \\
\text { microhardness; incr. fatigue } \\
\text { strength, life, } \& \text { stress } \\
\text { intensity range threshold; } \\
\text { reduced crack propagation } \\
\text { rate by factor of } 5 \text { to } 6\end{array}$ & $\begin{array}{l}\text { Berthe, et al., } \\
1998\end{array}$ \\
\hline
\end{tabular}

